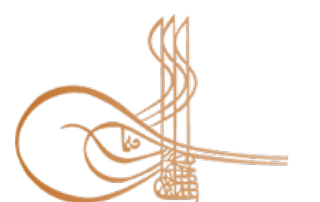

www.turkishstudies.net/economy
Turkish Studies - Economics, Finance, Politics

eISSN: $2667-5625$

Research Article / Araștırma Makalesi

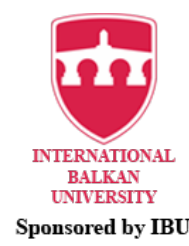

Sponsored by IBU

\title{
The Impact of ICT Patents on OECD Countries' Banks Risk Indicators and Discussion on the Use of Robotic Communication and Smart Glasses in the Banking Sector
}

\author{
Bilgi ve İletişim Teknolojileri Patentlerinin OECD Ülkelerinin Bankalarının Risk İndikatörlerine \\ Etkileri ve Robotik Illetişimin ve Akıllı Gözlüklerin Bankacılık Sektöründe Kullanımı ile İlgili \\ Tartışma
}

\author{
Hüseyin Çetin ${ }^{*}$
}

\begin{abstract}
The main objective of that research is to find out the influence of ICT patents on OECD banks' risk indicators such as cost/income, return on assets, and return on equity between the period of 2005-2013. Other objectives are to research current applications of robotic technologies and smart glass usage in the banking sector; and to discuss probable applications of robotic applications and smart glass usage in banking operations. Panel quantile regression analysis was implemented to unearth the impact of ICT patents on cost/income ratios of OECD countries' banks. In addition, Bayesian impulse response analysis was used to find the one standard deviation positive shock of OECD countries' banks ICT patents on the risk indicators of OECD countries' banks. Johansen panel cointegration analysis was implemented for the long term relationship between cost/income and ICT patents. Since no data were available for robotic applications and smart glasses usage in the banking sector, empirical analyses for robotic applications and smart glasses were not done. According to the panel quantile regression analysis result, ICT patents had a significant negative influence on OECD countries' banks cost/income ratio between 2005-2013. Bayesian impulse response analysis was implemented for return on assets, return on equity, cost/income ratio. The positive impact was found for return on asset, return on equity, and the negative effect was found for the cost/income ratio. ICT patents positive innovation impact has more influence on return on equity with respect to return on assets. Johansen panel cointegration test unearthed that there is a long-term relationship between ICT and cost/income ratios. It can be indicated that ICT patent production is useful for diminishing banks' costs. Moreover, robotic communication in banks can enhance the banking sector cost efficiency. Robotic communication with other banks and inside the bank can have an important influence on the development of the banking sector. Besides, it is possible that banks employees can use smart glasses. Smart glasses can be used for fraud detection, such as diagnosis of fake checks (Deloitte,2016). Currently, smart glass technology is immature; when the smart glass technology becomes mature, bank employees can use that technology.
\end{abstract}

\footnotetext{
* Dr. Öğr. Üyesi, Bursa Teknik Üniversitesi, İnsan ve Toplum Bilimleri Fakültesi, Uluslararası Ticaret ve Lojistik Bölümü Assistant Professor, Bursa Technical University, Faculty of Humanities and Social Sciences/Department of International Trade And Logistics

ORCID 0000-0001-7296-0447

huseyin.cetin@btu.edu.tr

Cite as/ Atıf: Çetin, H. (2020). The impacts of ICT patents on OECD countries' banks risk indicators and discussion on the use of robotic communication and smart glasses in the banking sector. Turkish Studies - Economy, 15(2), 799816. https://dx.doi.org/10.29228/TurkishStudies.42916

Received/Geliş: 15 April/Nisan 2020

Accepted/Kabul: 20 June/Haziran 2020

Copyright $($ INTAC LTD, Turkey
} 


\section{Structured Abstract: Purpose}

The emerging demands of consumers have been stated by Coras et al. (2015). The evolution of technology and an increasingly competitive world drives banks to evaluate new sources for competitive advantages, turning their attention to innovation (Coras et al. 2015).

Industrial Revolution 4.0 is a phenomenon that has a considerable effect on all facets of socioeconomic life in almost all human-related fields such as finance, banking, manufacturing, back-office, etc. Robotic Process Automation (RPA) is one of the most important discoveries. A crucial benefit of RPA is that, unlike previous IT implementations such as Enterprise Resource Planning (ERP), RPA does not entail an enormous upfront investment or a substantial shift in current IT structures and processes. RPA can be completed relatively rapidly compared to previous digital transformations, since it requires minimum resources or infrastructure. RPA may serve as an extra staff that can work within IT systems and back-office processes across several functions. Likewise, for humans, RPA will learn from people and duplicate their operations in due course, taking over the methods that humans have accomplished at a much faster speed (Chuong et al., 2019).

The smart glasses are small devices that can incorporate virtual reality, according to Qulix Systems (2016). Smart glasses can contact and send instant messages. Also, smart glasses can take photos and videos, too. Besides, smart glasses offer enormous potential for the banking sector. Smart glasses allow customers more digital control over financial transactions. Many smart glasses can do transactions for online banking (Qulix Systems, 2016).

Moreover, smart glasses can be used for controlling whether the check is fake or not. The usage of smart glass for check validation has four stages. In the first step, a client gives the bank teller a check. In the second step, the usage of smart glasses begins. Although a bank teller manages the customer's account, smart glasses recognize that process. In the third stage, smart glasses classify the search as suspicious by comparing the routing number with information from the Federal Reserve Bank Services. The smart glasses in the fourth stage warn the bank teller that they would not approve the order. Bank Teller would then converse with the customer while smart glasses would then automatically report the incident to their account (Deloitte, 2016). It can be indicated that the step-by-step usage of smart glasses may help determine whether a check is bogus or not.

The primary purpose of this research is to determine the influence of ICT patents on the risk indicators of OECD banks, such as cost/income, return on assets and return on equity between 2005-2013. Other goals include researching current applications of robotic technologies and smart glass in the banking sector and discussing possible untapped applications of robotic applications and smart glass usage in banking operations.

\section{Methodology}

In the methodology section, first, the panel quantile regression test was implemented to find the impact of OECD countries' banks cost/income ratios. In that test, ROA was used as a control variable. The panel quantile regression test was implemented with tau $=0.90$.

After the panel quantile regression test, Bayesian impulse response analysis was implemented to find the one standard deviation shock of ICT patents on the risk indicators of OECD countries banks. Before embarking Bayesian Impulse Response analysis, Bayesian VAR was implemented. Ideal lag lengths were chosen with AIC.

Unit root analyses were implemented to find the sustainability of ICT patents of OECD countries. Panel unit root analysis was also done for the cost/income ratio of OECD countries' banks.

Johansen Fisher panel cointegration test was implemented to unearth the long-term relationship between ICT patents and cost/income ratios of the OECD countries' banks. Macro and micro cointegration tests were done.

\section{Conclusion}

In that research, it was found that ICT patents had a significant negative influence on the panel dataset of OECD countries' banks cost/income ratios between the period of 2005-2013. It can be indicated that information and communication technology patents were also used to diminish banks' costs in the OECD region. 
Moreover, the Johansen Fisher panel cointegration test was applied for the panel datasets of ICT and cost/income ratios of OECD countries' banks. It was unearthed that there is a long-term relationship between those variables. In addition, micro cointegration analysis was also applied to the panel dataset. It was found that there is a long-term relationship between ICT patents and cost/income ratios for many OECD member countries' banks. Nevertheless, for many countries, at most, one cointegrating link was found.

Besides, Bayesian impulse response analysis was also implemented for OECD countries' banks risk indicators. When one standard deviation positive shock is given to ICT patents, return on assets, and return on equity of OECD countries' banks increases. It was found that the return on equity increased faster than the return on assets. Moreover, positive shocks of ICT patents diminishes the cost/income ratio. That result corresponds with panel quantile regression results with tau 0.90 .

Unit root analyses were implemented for cost/income ratio and ICT patents. It was found that the cost/income ratio did not increase steadily, and ICT patent production did not increase steadily as well. Since there is no unit root problem, ICT patent production is mean-reverting. Therefore, OECD members, in general, shall regularly increase ICT patent production. If that increases can also be applied in banking sectors, more innovations such as robotic technologies and smart glasses can be applied to the banking sector.

OECD countries can increase ICT patents about robotic technologies and smart glasses. To make those technologies more applicable, banks can open new research and development laboratories and can have partnerships with universities, engineering firms, and business consulting firms. Before implementing these technologies, simulation analyses have to be done by banks. After the simulations, the pros and cons of robotic technologies and smart glass applications can be determined. After minimizing the errors, banks can update and release robotic and smart glass applications.

Keywords: Banking Operations, ICT, Robotic Communication, Smart Glasses, Banks' Risk İndicators

Öz: Bu araştırmanın temel amacı, bilgi ve iletişim teknoloji patentlerinin 2005-2013 dönemi arasında maliyet/gelir, varlıkların getirisi ve özkaynak karlılı̆ı gibi OECD bankalarının risk göstergeleri üzerindeki etkisini bulmaktır. Diğer amaçlar bankacılık sektöründeki robotik teknolojilerin ve akıllı gözlük kullanımının güncel uygulamalarını araştırmak; bankacılık uygulamalarında robotik uygulamaların olası uygulamalarını ve akıllı gözlük kullanımını tartışmaktır. Bilgi iletişim teknoloji patentlerinin OECD ülkeleri bankalarının maliyet/gelir oranları üzerindeki etkisini ortaya çıkarmak için panel kantil regresyon analizi uygulanmıştır. Ayrıca, OECD ülkeleri bankalarının bilgi iletişim teknoloji patentlerinin OECD ülkeleri bankalarının risk göstergeleri üzerindeki bir standart sapma pozitif şokunu bulmak için Bayesian etki tepki analizi kullanılmışır. Risk göstergeleri ile bilgi ve iletişim teknoloji patentleri arasındaki uzun vadeli ilişsi için Johansen panel eşbütünleşme analizi uygulanmıştır. Bankacılık sektöründe robotik uygulamalar ve akıllı gözlük kullanımı için veri bulunmadığından, robotik uygulamalar ve akıllı gözlükler için ampirik analiz yapılamamıştır. Panel kantil regresyon analizi sonucuna göre, bilgi iletişim teknoloji patentlerinin 2005-2013 yılları arasında OECD ülkelerinin banka maliyet/gelir oranları üzerinde önemli bir olumsuz etkisi olmuştur. Aktif getirisi, özkaynak getirisi, maliyet/gelir oranı için Bayesian etki tepki analizi uygulanmıştır. Varlık getirisi, özkaynak getirisi için pozitif etki, maliyet/gelir oranı için negatif etki bulunmuştur. Bilgi ve iletişim teknoloji patentlerinin pozitif inovasyon etkisi, varlıkların getirisine göre özkaynak getirisi üzerinde daha fazla etkiye sahiptir. Johansen panel eşbütünleşme testi, bilgi iletişim ve teknoloji patentlerinin maliyet/gelir rasyoları arasında uzun vadeli bir ilişki olduğunu ortaya çıkarmıştır. Bilgi ve iletişim teknoloji patent üretiminin bankaların maliyetini azaltmak için yararlı olduğu söylenebilir. Ayrıca, bankalarda robotik iletişim bankacıllk sektörünün maliyet verimliliğini artırabilir. Diğger bankalarla ve banka içindeki robotik iletişimin bankacılık sektörünün gelişimi üzerinde önemli bir etkisi olabilir. Ayrıca akıllı gözlüklerin banka çalışanları tarafından kullanılabilmesi mümkündür. Akıllı gözlükler, sahtekarlık tespiti (sahte çek tespiti gibi) için kullanılabilir. (Deloitte,2016) Günümüzde akıllı gözlük teknolojisi olgunlaşmamış, akıllı gözlük teknolojisi olgunlaş̧ı̆ıında, banka çalışanları bu teknolojiyi kullanabilir.

Anahtar Kelimeler: Bankacılık Operasyonları, Bilgi ve İletişim Teknolojileri, Robotik İletişim, Akıllı Gözlükler, Bankaların Risk İndikatörleri 


\section{Introduction}

Information and communication technologies are significant for any business activity. In the 21 st century, it is indispensable for many businesses to implement ICT. Banks must adopt new technologies to enhance banking operations. Information and communication technologies are widely used in banking operations. Many OECD countries endeavor to increase ICT patents. Many banks are focusing on growing investments to advance software programs.

In the banking literature, there are limited studies about the influence of ICT patents on risk indicators of banks. Moreover, there are also limited studies about robotic communication and smart glass applications for the banking sector. Augmentation of ICT patents can be an essential milestone for financial innovation in the banking industry. Also, that research aims to shed light on the development of robotic communication and usage of smart glasses in the banking sector.

In the second section, the literature review will be conducted. Moreover, robotic technologies and smart glass topics will be covered in other sections. Since there is no data about robotic applications and smart glass usage, methodological design will be done in accordance with the relationship between ICT patents and risk indicators of OECD countries' banks. Recommendations will be given about the usage of robotic technologies and smart glass usage in the banking sector.

The main objective of that research is to find out the relationship between ICT patents and risk indicators of OECD countries' banks from 2005 to 2013. Another purpose is to research current applications of robotic technologies and smart glass usage in the banking sector; and to discuss probable applications of robotic applications and smart glass usage in banking operations.

\section{Literature Review}

In the literature, many studies explain the positive influence of technologies on banking sector development. Moreover, since researches about robotic communication and smart glass usage is limited, few studies were retrieved about those research topics.

Roberts and Amit (2003) analyzed the relationship between innovation and the appearance of segregated competitive positions in Australian retail banking. They found that innovative operations significantly and positively influence Australian banks' financial performance, giving importance to innovation.

Based on current non-bank financial services deregulation and the boom in e-money and ecommerce technologies, new network, retail and financial service provider alliances are on the edge of developing a whole set of integrated, innovative banking and finance platforms. (Schulz, 2005).

Abir and Chokri (2010) analyzed the adoption of new financial instruments for Tunisian banking for the period between 1997-2008. They mentioned that the legal system significantly influenced the innovations of the Tunisian banking sector.

Domeher et al. (2014) analyzed the causes that impact the adoption of financial innovation in Ghana's banking industry. Surveys were used for six important Ghana banks' 405 clients. By implementing logistic regression, it was unearthed that lack of complexity, compatibility, and perceived usefulness assisted by financial innovation increase the probability of e-banking adoption.

Banks are perceived as weak in innovation. Yet, rapidly changing needs of customers, technological development, competition pressure, and binding regulatory constraints force banks to look for new models of competitive advantage sources, shifting their focus towards innovation (Coras et al. 2015).

Kołodziej (2017) has proved that the implementation of virtual and augmented reality in the banking sector can create advantages for competition and enhances the efficiency of banking activity. 
By using quarterly data between 2006 and the second quarter of 2015, Gundogdu and Taskin (2017) researched the impact of internet banking usage and ATM usage and credit card usage on return on assets, return on equity, and net interest margins of Turkish banks. They found that internet banking and ATM usage do not have an essential influence on the performance of the Turkish banking system. They unearthed that only credit card usage had a significant positive impact on return on assets, return on equity, and net interest margin of Turkish banks.

Chaarani and Abiad (2018) researched the impact of technological innovation factors on the performance of Lebanese banks between the period of 2010-2017. It was unearthed that internet banking and ATM had a positive influence on Lebanese banks' returns. Nevertheless, mobile banking and investments in computer software had a non-significant impact on Lebanese banks' performances.

Robotic process automation can be utilized for the collection of data and data analysis. Nevertheless, customers are worried about security and personal data privacy. The practical implementation of this new technology can also be part of a bank's competitive strategy that will bring advantages to the bank and its customers. Robotic Process Automation (RPA) is becoming a strategic preference for banks to sustain competitive advantage and augment profitability (Kumar, Balaramachandran, 2018).

According to Saha and Dasgupta (2018), cloud robotics has appeared recently as a collaborative technology between cloud computing and service robotics, enabled in recent years by advances in wireless networking, large-scale storage and communication technologies, and the increased internet resource usage. Cloud computing strengthens robots by parallel processing and more massive data storage facilities by providing them quicker and more efficient computational capabilities. It also offers access to open-source, complex data and software, collaborative learning capabilities via knowledge sharing, and crowdsourcing human knowledge.

Industrial Revolution 4.0 is a phenomenon that has a considerable effect on all facets of socio-economic life in almost all human-related fields such as finance, banking, manufacturing, back-office, etc. Robotic Process Automation (RPA) is one of the most important discoveries. A crucial benefit of RPA is that, unlike previous IT implementations such as Enterprise Resource Planning (ERP), RPA does not entail an enormous upfront investment or a substantial shift in current IT structures and processes. RPA can be completed relatively rapidly compared to previous digital transformations, since it requires minimum resources or infrastructure. RPA may serve as an extra staff that can work within IT systems and back-office processes across several functions. Likewise, for humans, RPA will learn from people and duplicate their operations in due course, taking over the methods that humans have accomplished at a much faster speed (Chuong et al., 2019).

\section{Discussion of Robotic Communication in Banking Sector}

Robots are mainly used to diminish the cost of the banks. With effective robotic communication, employees can focus more on value-added processes. Different robots in a particular bank can have different functions. Some robots can directly do the paperwork or assist the employees and respond to their requests. Other robots can be in the back office and can control the different processes of the banks. For example, robots can control the money counting machine. If a customer takes more or less money from money counting machines, a robot can directly communicate with bank employees and customers.

Robots can control the international trade payment system and smart contracts. For example, if two foreign banks are involved in international trade transactions such as letters of credit, two foreign banks robots can communicate with each other. If there is a problem during the operations, robots can be used for early warning systems to prevent issues such as legal problems, false information in documents, sudden changes in customs laws. The robots that received information 
first can communicate with other robots in foreign banks. If that system can be applied, international trade processes can be more fast and reliable.

Robots can use artificial intelligence techniques to detect any problems in branches and can report the issues to other robots that can exist in general administration. When reports went to master robots, robots can communicate with the general administration of the bank. The general administration can report the problem and update information and sent that information to the master robot. That master robot can distribute new knowledge to other robots in bank branches. Every business day, that kind of transaction shall continue to minimize the problems in banking operations.

Moreover, if an unexpected operational error happens, probable risk maps should be evaluated by robots, and robots can communicate with each other. They can give early warning to the general administration of the bank. Moreover, employee mistakes can even cause the bankruptcy of the bank. It can be indicated that detecting errors and managing risky operations is an essential step for robotic communication.

If a customer can not take back the credit card in ATM or if the credit card is stolen, robots can protect credit card information. A robot can introduce a new temporary credit card and that credit card can be sent to the mobile phone of the customer. Customers can continue transactions with a credit card that is embedded in mobile phones. If the credit cards can be used intensely in mobile phones, robotic technology can also be applied to remove the problem of customers.

\section{Robotic Application in Banking Industry}

Although robotic technologies are not widely used for the global banking sector, some banks had already embarked on robotic operations.

ICICI Bank in India has rolled out Smart Vault. That smart application is a fully automated locker. Customers can access the cabinet any time, and that technology reduces human interaction during locker operation. Radio Frequency Identification (RFID) examines the customer's demand and retrieves their locker utilizing a robotic arm from a powerful and protected vault (Agarwal et al., 2017).

Tokyo-Mitsubishi UFJ Bank has implemented a robot dubbed as Nao. Alderban electronics manufacture Nao. That robot can answer inquiries about processes one shall do about losing their credit card or assisting someone about opening a bank account in different languages. Nao is being utilized to converse with customers via inbuilt facial recognition software, reply to basic questions, thus helping staff to focus more on value-added services (Agarwal et al., 2017).

Barclays plans on utilizing robots for the assistance of money transfers and implements necessary charges. The bank can use an artificial intelligence system on the lines of Apple's iPhone assistant Siri. That can lead customers to talk with the device and take feedback (Agarwal et al., 2017).

Singapore DBS has implemented a wealth management system that is centered on Watson. Watson is developed by IBM and based on cloud base technology. The system can take colossal information, and learning occurs each interaction, assisting banks in analyzing information fast, perceive, and answer to immense details (Agarwal et al., 2017).

While instant banking has formed a comfortable area for the urban user, the next transformative operations would be robotic technology with faster speed, diminished cost, more diversifiable skills, enhanced efficiency, 24/7 services, and the better customer experience in the coming decades (Agarwal et al., 2017).

In addition to those applications, Albaraka Turk bank embarked robotic process automation project. Albaraka Press Newsletter indicated that robot software operates three times faster than the 
average staff and complete transactions error-free at \%100 efficiency for 24/7. Albaraka Turk Vice President Cetin mentioned that a single robot offers at least 15.000 Turkish lira savings per month, and return on investment (ROI) is more than $1200 \%$. Cetin also mentioned that savings for working hours are more than 600 hours per month (Albaraka Press Newsletter, 2018).

\section{Smart Glass Application}

The past of smart glasses can be traced back to the 1960s. Back in 1967, computer scientist Ivan Sutherland, with the aid of his students, designed the Damocles sword. While rough and somewhat identical to today's smart glasses, this product is commonly considered to be the first-ever augmented reality head-mounted display system. Quick forward to the 1980s and 1990s, when Canadian researcher Steve Mann embarked on research into his WearCamp (wearable computer) solution, which paved the way for smart glasses (Smart Glasses Hub).

Google glass was revolutionary; nevertheless, due to the privacy, it was not widespread. But, Form Swim Goggles launched a new period. Form Swim Goggles is a swimmer glass. It shows you burn calories, and due to its sensors, heart rate can also be measured. That information can be stored in smartphones (Akgul, 2019).

Smart glasses are a type of wearable device with a view-through head-mounted display (HMD). Usually, smart glasses are used to display details on the screen in front of the user's eye. Smart glasses can be monocular, such as Google Glass or binoculars. In recent years, several firms, including Sony, Google, and Samsung, have launched HMDs on the market. Tests with Google Glass, Optinvent ORA1, and other smart glasses reveal limitations on battery life, screen, and camera. The announced battery life of Google Glass for medium use is one to two hours, which is already a significant limitation in some instances of usage. During conducting tests with a simple scanning program, the battery's autonomy will be about 40 minutes. Nevertheless, after 15 to 20 minutes of heavy use, the tool begins to overheat and can not be used until it has had time to cool down. Besides, the device has a resolution of $640 \times 360$ pixels in full color, and can view videos at an appropriate frame rate. Nevertheless, the battery life of the computer is severely limited. Whenever a film or camera feed is seen, the system starts overheating. In addition to these drawbacks, the camera has a resolution of 5 megapixels and can capture $720 \mathrm{p}$ videos. While camera metrics should be more than adequate to search QR codes, they are not appropriate for business applications. The lack of autofocus thwarts QR code scanning (Mühlematter and Donno, 2016).

Mühlematter and Donno (2016) used a questionnaire to have information about Bank Credit Suisse employees about the usage of smart glass in the bank. When 31 staff were interviewed about the essential functions of smart glass, data security, battery life, and comfort were found as the most critical aspects of smart glass. Moreover, Mühlematter and Donno (2016) asked 30 staff about the recommendation of smart glass technology to other colleagues. It was found that $59 \%$ of 30 staff answered that they recommended smart glass technology to other staff. The authors also mentioned that due to a lack of maturity in smart glass technology, $41 \%$ of 30 employees did not recommend smart glass technology to other colleagues.

According to Qulix Systems, smart glasses are miniature computers that can integrate augmented reality. Smart glasses can send text messages and e-mail. Besides, smart glasses can also take pictures and videos. Moreover, smart glasses have immense potential for the banking sector. Smart glasses give consumers greater digital control for financial transactions. Many smart glasses can implement online banking transactions. They can also be able to make retail payments. Qulix Systems also mentioned that several banks in Spain provide smart glasses for underlying transactions (Qulix Sytems, 2016). 
According to Qulix Systems, as a result of face recognition technology, bank advisers can use smart glasses to identify the customers. Via implementing automatic online behavior analysis, the bank staff can perceive the customer's request (Qulix Systems, 2016).

According to Qulix Systems, customers can contact with bank for car loans with smart glasses. Like digital loans, customers can use smart glasses for loans without going to the bank. By utilizing a video or audio chat, the car loan can be approved. After that transaction, the money can be transferred to a car dealer (Qulix Systems, 2016).

According to Qulix Systems, integrated biometric technology with smart glasses can facilitate customers to withdraw money without any card. Thus, with the application of that technology, customers will not need to find an ATM. With that system, the customer can get the password directly on smart glasses (Qulix Systems, 2016).

Qulix Systems indicated that after a customer receives a bill in e-mail accounts, by using a smart glasses camera, customers can make a payment from anywhere (Qulix Systems, 2016).

The Vuzix M100 smart glasses are commercially available wearables that are designed specifically for enterprise use. Coupling a portable computer with wireless networking, camera, and GPS, this portable device has the potential to access the staff's surroundings without needing any extra effort. Although this technology is being tested in industrial environments, a similar tool may be used by a bank to recognize and classify items in real-time automatically. It may have a significant effect on a bank advisor or teller who needs to manually assess if a check is fake today (Deloitte, 2016). This method is shown step by step in Table 1 .

Table 1: The Smart Glass Usage for Validating Check

\begin{tabular}{|l|l|}
\hline Step 1 & $\begin{array}{l}\text { A customer goes to a bank and shows } \\
\text { a bank deposit check to the bank } \\
\text { teller. }\end{array}$ \\
\hline Step 2 & $\begin{array}{l}\text { Bank Teller looks at the check and } \\
\text { then begins checking the customer's } \\
\text { account on their computer. Smart } \\
\text { glasses recognized that the Bank } \\
\text { Teller is looking through the } \\
\text { receiver, number, and Magnetic Ink } \\
\end{array}$ \\
\hline Step 3 & $\begin{array}{l}\text { Character Recognition (MICR) line } \\
\text { to search and method. }\end{array}$ \\
& $\begin{array}{l}\text { Smart glasses assess that the check is } \\
\text { bogus by comparing the routing } \\
\text { number to the Federal Reserve Bank } \\
\text { Services database. }\end{array}$ \\
\hline Step 4 & $\begin{array}{l}\text { The Bank Teller is told by the smart } \\
\text { glasses that the check should not be } \\
\text { approved. Bank Teller is talking to } \\
\text { the customer, while smart glasses are } \\
\text { automatically logging the incident on } \\
\text { their account. }\end{array}$ \\
\hline
\end{tabular}

\section{Source: Deloitte (2016)}

The smart glass usage for validating check has four steps. In the first step, a customer gives a check to the bank teller. In the second step, smart glasses usage embarks. While a bank teller is controlling the customer's account, smart glasses acknowledge that process. In the third step, smart glasses determine the check as fraudulent by matching the routing number with the Federal Reserve Bank Services records. In the fourth step, the smart glasses inform the bank teller not to accept the request. Bank Teller converses with the customer, while smart glasses report the incident into their 
account automatically (Deloitte, 2016). It can be mentioned that using smart glasses step-by-step can be beneficial for determining whether a check is bogus or not.

\section{Discussion of Smart Glass Application in Banking Operations}

Smart glasses can be used for checks. If there is an overdraft check, the bank can utilize the smart glasses to evaluate the overdraft cheque. With that system, more reliable transactions can occur.

Form Swim Goggles can interact with the bank SMS system. For example, if a person swims and but suddenly has to do banking transactions, customers can do transactions with updated Swim Goggles. That can be possible if new technologies can be added to Form Swim Goggles.

Smart glasses can be used for artificial banking intelligence. A customer can get messages about the significant decrease in a bank account. When a substantial reduction in bank account occurs, smart glasses can offer an overdraft account or loan.

Smart glasses can be used to communicate with robots as well. Bank employees can use smart glasses to interact with robots. They can see robots' messages via smart glasses. Moreover, by using smart glasses, bank customers can communicate with robots, and when they ask questions via smart glasses, robots can be seen in smart glass screens, and they can communicate with customers. In addition to that, if a customer wants to talk with a customer representative, a customer can directly connect to the customer representative via smart glasses.

Smart glasses can be used in smart shopping as well. Customers can scan the goods with smart glasses and made the payment by credit card that is embedded in smart glasses. A credit card in smart glass can read the price of goods and can begin the provisioning process after the shopping.

If the customer can not find a credit card and does not have a mobile phone, smart glasses can use QR code, and the customer can withdraw money from the ATM.

In the case of banking applications, single-factor authentication is deemed inadequate. The standard variation is a physical token or a password, and a certificate. The use of a biometric functionality as the second element, such as a user's fingerprint, retina or iris, will also be possible in the future (Mühletmatter and Donno, 2016). At present, the use of smart glass in the banking sector is in its infancy. When biometric technology can be used effectively and safely, the use of smart glass by bank employees and customers can proliferate.

Augmented Truth (AR) has three characteristics. The first is that it blends the physical world with virtual knowledge, and the second is that it must be interactive in real-time. Third, the universe must have a virtual representation of it in three dimensions. In other words, AR is registered in 3-D. (Azuma,1997). Moreover, in an experiment, users had to perform a series of complex procedures with an AR unit. It was indicated that users had achieved faster task using the AR app compared to the LCD conditions (Henderson, Feiner, 2011). It can be said that if smart glasses can solve technological difficulties and become a standard product in banking operations, bank employees can make more productive use of time. Operational risk is common in the banking sector. The practical application of smart glasses can reduce the probability of bank operational risks that can be caused by employee errors.

\section{Methods}

Since there is no data about robotic applications and smart glasses usage in the banking sector, econometric analyses were not implemented about those research topics. In that section, the impact of ICT patents on OECD banks' risk indicators will be measured. E-views software was used for analyses. 


\subsection{Panel Quantile Regression}

Standard linear regression techniques epitomize the average relationship between a set of independent variables and the dependent variable based on the conditional mean function $\mathrm{E}(\mathrm{y} \mid \mathrm{x})$. This provides only a slight part of the relationship. Quantile regression can explain the relationship at different points in the conditional distribution of y (Baum, 2013). The quantile regression model is described as follows (Yavuz, Asık, 2017).

$$
\mathrm{y}_{\mathrm{i}}=\mathrm{x}_{\mathrm{i}}{ }^{\prime} * \beta_{\mathrm{q}}+\mathrm{u}_{\mathrm{q}}
$$

In the first equation, $x_{i}$ indicates the independent vector of independent variables. $B_{q}$ is a parameter vector that is based on $q$ th quantile. Moreover, $\mathrm{u}_{\mathrm{q}}$ indicates the residual (Yavuz, Asik, 2017).

Panel data can use non-parametric data and can convert non-parametric data to parametric data. In order words, panel data can collect the data of countries and combine them with time interval. In that research, panel data quantiles will be used; random data will be withdrawn from the panel data set.

Panel quantile regression analysis will be implemented with tau $=0.9$. Tau is the same with $\mathrm{q}$ in the above equation. In other words, tau indicates the total withdrawal percentange of sample size. In order to have a more valid result, $90 \%$ of random data will be withdrawn. Moreover, the dependent variable is the OECD banks' cost/income ratio. Patent data were retrieved from the OECD Stat Database. Moreover, banking sector data were retrieved from the Global Financial Development Database. The independent variable is OECD countries' information and communication technology patents. Since recent data was not available, the time interval will be 2005-2013. Moreover, in panel data-based time series analysis, annual data were used. The hypothesis test was constructed. Hausman test was used. Since the p-value is less than 0.05 , a random effect was rejected. Then the research hypothesis with a fixed effect was formed.

H1: Between 2005-2013, ICT Patents had a significant negative impact on OECD banks' cost/income ratios with tau $=0.90$.

In that model, since the fixed effect will be used, the intercept and the first lag of the dependent variable will be added to the analysis.

In the panel quantile regression analysis, return on assets was used as a control variable. The first equation is expanded as follows. In the equation, $a_{i}$ indicates the intercept value. ICT and return on assets (ROA) indicate independent variables, and $u_{i t}$ shows the residuals of panel data analysis. After determining dependent and independent variables, I constructed the following equation.

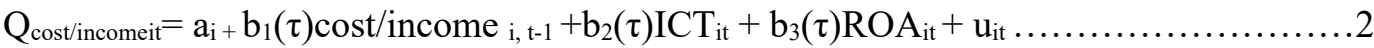

After constructing the second equation, panel quantile regression analysis is implemented. Quantile process Estimates

$10 \mathrm{~T}$

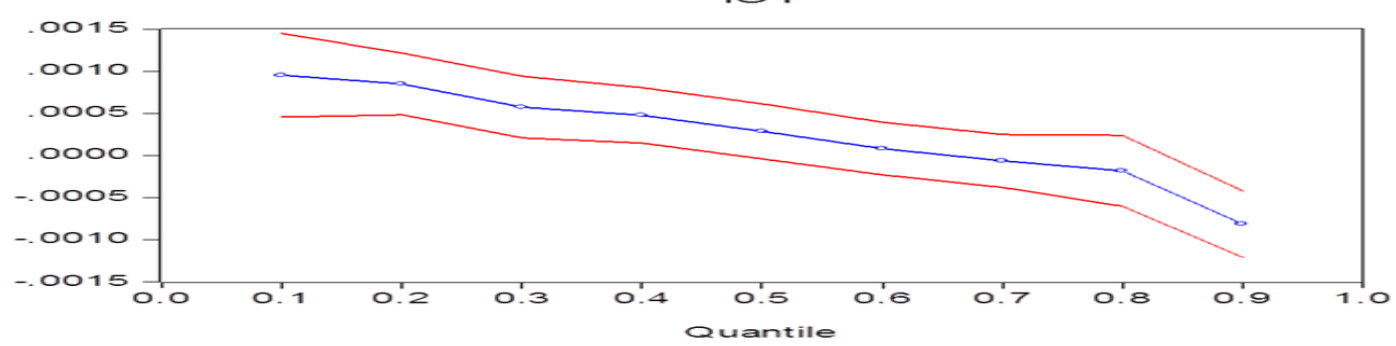

Figure 1: Quantile Process Estimates 
Quantile process estimates (Figure 1) showed that when quantiles(tau) increase, the positive impact of ICT on OECD countries' banks cost/income ratio plummeted. The quantile process estimates with fixed effects were calculated. With tau 0.9 , the negative impact is unearthed. Table 2 shows the panel quantile regression analysis result.

Table 2: Panel Quantile Regression Analysis (2005-2013)

\begin{tabular}{|l|l|l|}
\hline Variable & Coefficient & Prob \\
\hline $\mathrm{C}$ & 15.73 & 0.00 \\
\hline Cost/ Income (-1) & 0.89 & 0.00 \\
\hline ICT & & \\
\hline ROA & -0.000813 & 0.00 \\
\hline
\end{tabular}

According to Table 2 result, hypothesis 1 is accepted. In other words, ICT had a significant negative influence on the change of OECD countries' banks cost/income ratios between the period of 2005-2013. Moreover, R-square was found as 0.47.

\subsection{Bayesian Impulse Response Analysis}

Before embarking Bayesian Impulse Response analysis, Bayesian VAR was implemented. Ideal lag lengths were chosen with AIC. Bayesian impulse response analysis is about the innovation impact of an independent variable on the dependent variable. In that step, the main objective is to find the comparative ICT innovation impact on change of the risk indicators, which are cost/income, return on assets and return on equity. For three analyses, AR Polynomial Root graphs were analyzed. Since dots are inside the circle, no model stability problem was diagnosed. All data were first differenced.

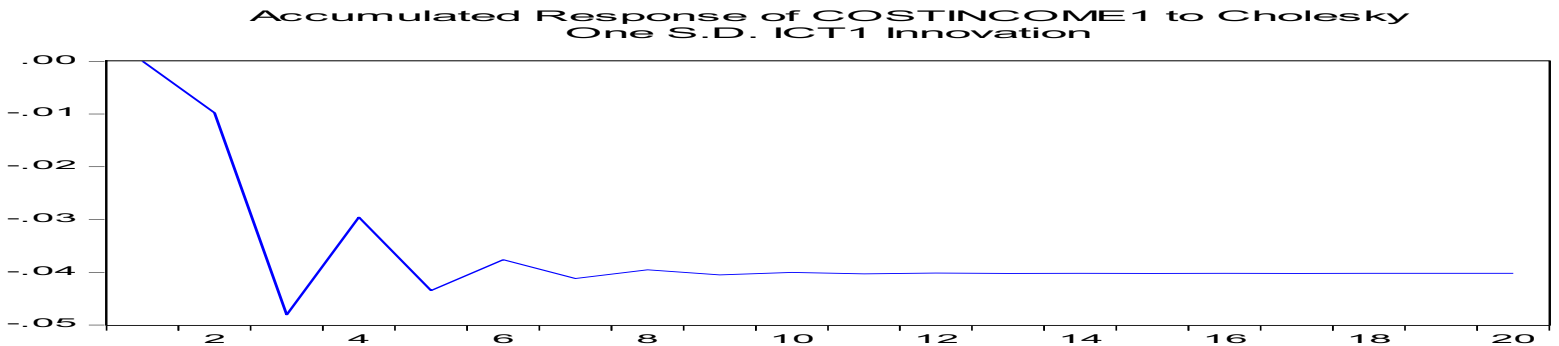

Figure 2: Bayesian Impulse Response-Cost/Income-ICT

Bayesian VAR was implemented with an ideal lag length of two. Figure 2 shows that when one standard deviation positive shock is implemented, cost/income diminishes for the period between 2005-2013. That research result corresponds with the panel quantile regression result.

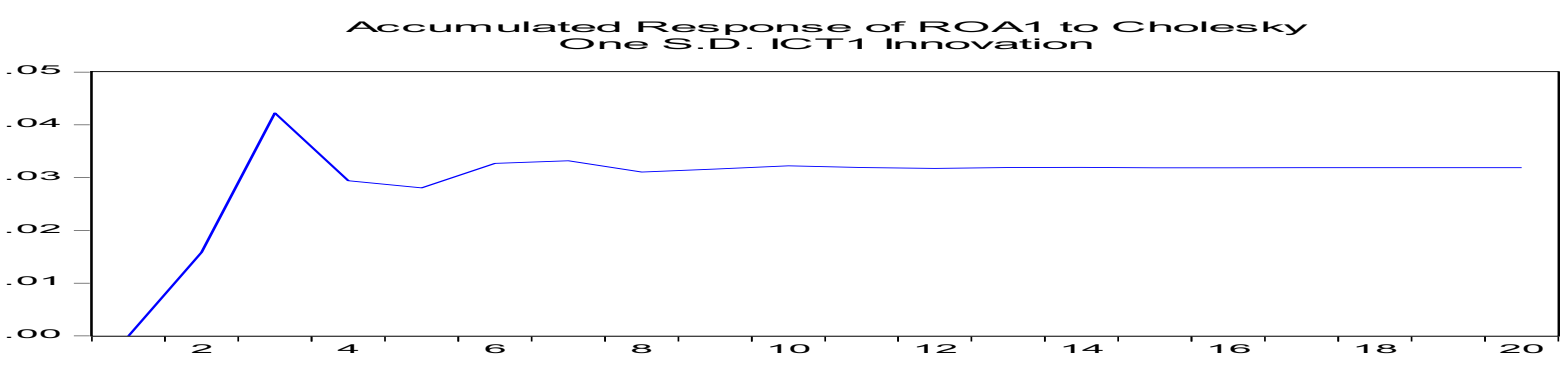

Figure 3: Bayesian Impulse Response-Return on Assets-ICT 
Bayesian VAR was implemented with a lag length of two. Figure 3 indicates that when one standard deviation positive shock is implemented, OECD banks' return on assets increases within the period of 2005-2013.

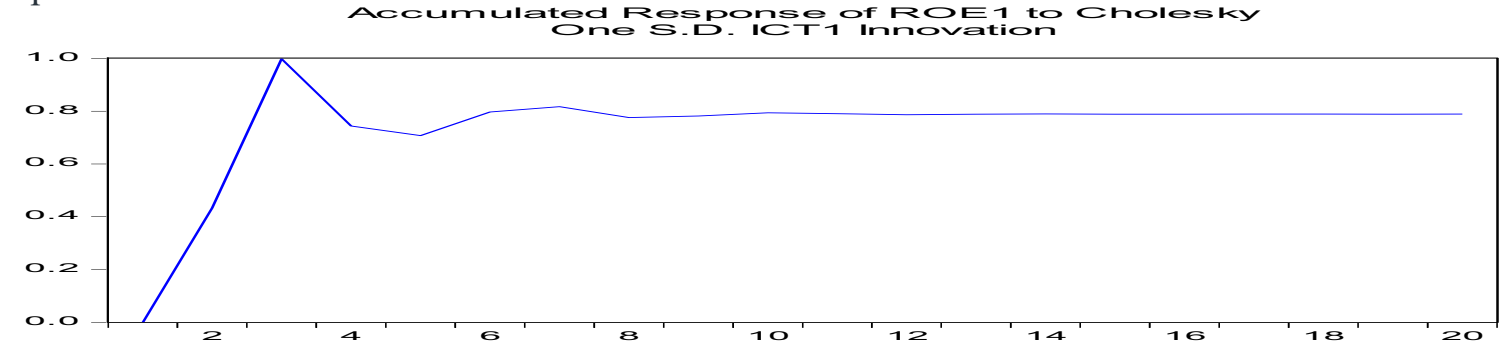

Figure 4: Bayesian Impulse Response-Return on Equity-ICT

Bayesian VAR was implemented with a lag length of three. Figure 4 shows that when one standard deviation positive innovation shock is applied, OECD banks' return on equity increases within the period of 2005-2013. According to analysis results in Figure 3 and Figure 4, it can be mentioned that for one standard deviation positive shock of ICT, return on equity reacts faster than return on assets for OECD banks panel datasets.

\subsection{Unit Root Analysis of OECD Countries' ICT Patents}

In that analysis, the main objective is to find out the sustainability of OECD members ICT patents. Panel unit root analysis was implemented. The exogenous variable was used as an individual effect. Newey-West bandwidth selection and Bartlett kernel was used. Hausman test showed that the fixed effect would be used in the model.

Table 3: Unit Root Analysis of ICT Patents

\begin{tabular}{|l|l|l|}
\hline Method & p value & Observation \\
\hline Levin, Lin, Chu & $\mathbf{0 . 0 0}$ & $\mathbf{2 3 8}$ \\
\hline Im, Peseran, Shin & 0.00 & 238 \\
\hline
\end{tabular}

Table 3 shows that there is no unit root problem for the ICT patent. That means information and communication technology patent production converges to its mean value. In other words, there is a mean-reversion process. It can be mentioned that ICT patents did not increase fast. That circumstance can plummet financial innovation patents that are based on ICT. If there are less financial innovation patents that are based on ICT, banking sector efficiency may be influenced adversely.

\subsection{Unit Root Analysis of OECD Countries' Banks Cost/Income Ratio}

In that analysis, the objective is to unearth the trend of cost/income ratio.

Table 4: Unit Root Analysis of Cost/Income

\begin{tabular}{|l|l|l|}
\hline Method & p value & Observation \\
\hline Levin, Lin, Chu & $\mathbf{0 . 0 0}$ & $\mathbf{2 3 0}$ \\
\hline Im, Peseran, Shin & 0.17 & 230 \\
\hline
\end{tabular}

According to Levin, Lin, Chu's unit root test, there is no unit problem for the banks of OECD countries. Besides, according to Im, Peseran, Shin's unit root test result, there is a unit root problem. Egeli et al. (2017) mentioned that the fixed effect would be used in homogenous panel data models. It was mentioned that fixed effects could be used in Levin, Lin, Chu's unit root tests. Since fixed 
effect exists in the panel data model, Im, Peseran, Shin method will be neglected. Therefore, before implementing the Johansen panel cointegration test, Levin, Lin, Chu unit root test was applied. It was found that there is no unit root problem for the banks of OECD countries.

\subsection{Johansen Fisher Panel Cointegration Test}

Johansen Fisher Panel Cointegration test was implemented to unearth the long-term relationship between ICT patents and cost/income ratios of the OECD countries' banks. For I (0), there was no unit root problem for ICT patents and cost/income ratios. For I (1), the same analyses were applied. No unit root problem again was found for the series. In order to remove the linear combination problem, Johansen Fisher Panel Cointegration test will be applied with the I (0) series.

Table 5: Johansen Fisher Panel Cointegration Test

\begin{tabular}{|l|l|l|l|}
\hline $\begin{array}{l}\text { Fisher } \\
\text { Stat } \\
\text { (Trace) }\end{array}$ & Prob & $\begin{array}{l}\text { Fisher } \\
\text { Stat } \\
\text { from } \\
\text { max- } \\
\text { eigen } \\
\text { Test }\end{array}$ & Prob \\
\hline 424.5 & 0.00 & 396.4 & 0.00 \\
\hline 114.7 & 0.00 & 114.7 & 0.00 \\
\hline
\end{tabular}

For none and at most one, the null hypothesis is rejected for cointegrating equations. The long-term relationship between ICT patents and cost/income ratios of OECD countries' banks was found. Micro Johansen panel cointegration analysis was implemented. Table 6 shows individual cross-section results.

Table 6: Individual Cross Section Results

\begin{tabular}{|c|c|c|c|c|}
\hline \multirow[b]{2}{*}{ Cross Section } & \multirow{2}{*}{$\begin{array}{l}\text { Trace Test } \\
\text { Statistics }\end{array}$} & \multicolumn{3}{|c|}{ Max-Eign Test } \\
\hline & & Prob.** & Statistics & Prob.** \\
\hline \multicolumn{5}{|c|}{ Hypothesis of no cointegration } \\
\hline Australia & 43.8798 & 0.0000 & 25.5597 & 0.0011 \\
\hline Austria & 36.5500 & 0.0001 & 24.7328 & 0.0016 \\
\hline Belgium & 47.2505 & 0.0000 & 38.5463 & 0.0000 \\
\hline Canada & 19.0836 & 0.0720 & 10.8832 & 0.2606 \\
\hline Chile & 42.1286 & 0.0000 & 29.0432 & 0.0003 \\
\hline Czech & 36.6657 & 0.0001 & 30.9791 & 0.0001 \\
\hline Denmark & 21.1500 & 0.0377 & 17.9202 & 0.0237 \\
\hline Estonia & 30.0882 & 0.0016 & 28.3431 & 0.0004 \\
\hline Finland & 16.2218 & 0.1643 & 9.5046 & 0.3816 \\
\hline France & 12.6307 & 0.3940 & 7.9055 & 0.5590 \\
\hline Germany & 41.1979 & 0.0000 & 35.5709 & 0.0000 \\
\hline Greece & 20.4662 & 0.0469 & 18.9111 & 0.0163 \\
\hline Hungary & 32.4066 & 0.0007 & 30.5476 & 0.0001 \\
\hline
\end{tabular}




$\begin{array}{cr}\text { Ireland } & \\ \text { Israel } & 11.9753 \\ \text { Italy } & 34.7923 \\ \text { Japan } & 40.9500 \\ \text { Korea } & \end{array}$

Latvia

Lithuania

Luxembourg

Mexico

Netherlands

New Zealand

Norway

Poland

Portugal

Slovak

Slovenia

Spain

Sweden

Switzerland

Turkey

UK

USA
29.7220

49.4751

15.9854

28.1029

19.1389

25.8466

15.8827

66.3458

26.6210

17.9990

23.1839

52.1264

11.8786

17.7396

53.8261
Dropped from Test

$\begin{array}{lll}0.4510 & 7.5457 & 0.6027 \\ 0.0003 & 26.7739 & 0.0007 \\ 0.0000 & 36.4793 & 0.0000\end{array}$

Dropped from Test

Dropped from Test

$\begin{array}{lll}0.0018 & 26.2335 & 0.0009 \\ 0.0000 & 38.5069 & 0.0000 \\ 0.1751 & 13.1845 & 0.1272 \\ 0.0034 & 24.4742 & 0.0018\end{array}$

Dropped from Test

$\begin{array}{lll}0.0708 & 15.5015 & 0.0575 \\ 0.0076 & 18.5460 & 0.0187 \\ 0.1799 & 14.0022 & 0.0968 \\ 0.0000 & 57.7526 & 0.0000 \\ 0.0058 & 17.4274 & 0.0285 \\ 0.0995 & 16.4653 & 0.0406 \\ 0.0192 & 19.3309 & 0.0138 \\ 0.0000 & 46.0587 & 0.0000 \\ 0.4597 & 9.5899 & 0.3732 \\ 0.1073 & 13.1981 & 0.1266 \\ 0.0000 & 39.7172 & 0.0000\end{array}$

Hypothesis of at most 1 cointegration relationship

$\begin{array}{ccccc}\text { Australia } & 18.3201 & 0.0008 & 18.3201 & 0.0008 \\ \text { Austria } & 11.8173 & 0.0153 & 11.8173 & 0.0153 \\ \text { Belgium } & 8.7042 & 0.0611 & 8.7042 & 0.0611 \\ \text { Canada } & 8.2004 & 0.0760 & 8.2004 & 0.0760 \\ \text { Chile } & 13.0854 & 0.0086 & 13.0854 & 0.0086 \\ \text { Czech } & 5.6866 & 0.2164 & 5.6866 & 0.2164 \\ \text { Denmark } & 3.2299 & 0.5386 & 3.2299 & 0.5386 \\ \text { Estonia } & 1.7450 & 0.8277 & 1.7450 & 0.8277 \\ \text { Finland } & 6.7171 & 0.1421 & 6.7171 & 0.1421 \\ \text { France } & 4.7252 & 0.3149 & 4.7252 & 0.3149 \\ \text { Germany } & 5.6270 & 0.2216 & 5.6270 & 0.2216 \\ \text { Greece } & 1.5550 & 0.8634 & 1.5550 & 0.8634 \\ \text { Hungary } & 1.8590 & 0.8056 & 1.8590 & 0.8056 \\ \text { Ireland } & & \text { Dropped from Test } & & \\ \text { Israel } & 4.4296 & 0.3519 & 4.4296 & 8.0183 \\ \text { Italy } & 8.0183 & 0.0822 & 0.3519\end{array}$

Turkish Studies - Economy, 15(2) 


\begin{tabular}{ccccc}
\hline Japan & 4.4707 & $\begin{array}{c}0.3465 \\
\text { Dropped from Test } \\
\text { Korea }\end{array}$ & 4.4707 & 0.3465 \\
Latvia & & Dropped from Test & \\
Lithuania & 3.4885 & 0.4936 & 3.4885 & 0.4936 \\
Luxembourg & 10.9682 & 0.0225 & 10.9682 & 0.0225 \\
Mexico & 2.8009 & 0.6186 & 2.8009 & 0.6186 \\
Netherlands & 3.6287 & 0.4702 & 3.6287 & 0.4702 \\
New Zealand & & Dropped from Test & & \\
Norway & 3.6375 & 0.4688 & 3.6375 & 0.4688 \\
Poland & 7.3005 & 0.1114 & 7.3005 & 0.1114 \\
Portugal & 1.8805 & 0.8013 & 1.8805 & 0.8013 \\
Slovak & 8.5932 & 0.0641 & 8.5932 & 0.0641 \\
Slovenia & 9.1936 & 0.0494 & 9.1936 & 0.0494 \\
Spain & 1.5336 & 0.8673 & 1.5336 & 0.8673 \\
Sweden & 3.8530 & 0.4344 & 3.8530 & 0.4344 \\
Switzerland & 6.0677 & 0.1856 & 6.0677 & 0.1856 \\
Turkey & 2.2887 & 0.7198 & 2.2887 & 0.7198 \\
UK & 4.5414 & 0.3375 & 4.5414 & 0.3375 \\
USA & 14.1089 & 0.0054 & 14.1089 & 0.0054
\end{tabular}

Table 6 indicates that there is a long-term relationship between ICT patents and the cost/income ratio for many OECD member countries. Moreover, when the hypothesis of at most one cointegrating relationship is analyzed, it was unearthed that only Australia, Austria, Chile, Luxembourg, Slovenia, USA, has more than one cointegrating relationship.

It can be indicated that many OECD members have used ICT patents successfully to diminish banks' cost/income ratios. There is a disequilibrium between many OECD countries' banks cost/ income ratios and ICT patents in the short term. According to analysis, it is expected for many OECD countries' banks, disequilibrium between many OECD countries' banks cost/income ratios, and ICT patents convert to the equilibria process. The analysis highlight that when OECD member countries increase their ICT patents in the future, it is highly prospective that usage of ICT patents will have a stable negative relationship with the cost/income ratios of many OECD countries' banks. If OECD countries produce more information and communication technology patents, new robotic and smart glass technologies can unearth. The robotic technologies and smart glasses technologies derived from ICT patents can enhance the banking sector efficiency accordingly.

Moreover, some countries' ICT patents do not have long term relationships with cost/income ratios. For example, Turkey is one of the OECD member countries that does not have long-term relationships between ICT patents and banks' cost/income ratio. To have more sustainable long term negative relationship between ICT patents and cost/income ratios of Turkey's banks, Turkey has to increase information and communication technologies research and development budget and can roll out more ICT patents and apply those patents on robotic processes and smart glasses technologies to develop banking processes and increase the efficiency of Turkey's banks. There can be disequilibria between ICT patents and the cost/income ratio. Still, if ICT patents increase and be utilized efficiently, there can be long term negative stable relationship between ICT patents and cost/income ratios of Turkey's banks. Currently, there is a slight implementation of robotic process automation in 
Turkey's banks. Robotic process automation is intensely used in the automobile industry of Turkey. However, robotic technologies can also be more intensely implemented for the efficiency of the service sector, such as the banking sector efficiency.

\section{Conclusion}

In that research, it was found that ICT patents had a significant negative influence on the panel dataset of OECD countries' banks cost/income ratios between the period of 2005-2013. It can be indicated that information and communication technology patents were also used to diminish banks' costs in the OECD region.

Moreover, the Johansen Fisher panel cointegration test was applied for the panel datasets of ICT and cost/income ratios of OECD countries' banks. It was unearthed that there is a long-term relationship between those variables. Moreover, micro cointegration analysis was also applied to the panel dataset. It was found that there is a long-term relationship between ICT patents and cost/income ratios for many OECD member countries' banks. Nevertheless, for many countries, at most, one cointegrating link was found.

Besides, Bayesian impulse response analysis was also implemented for OECD countries' banks risk indicators. When one standard deviation positive shock is given to ICT patents, return on assets, and return on equity of OECD countries' banks increases. It was found that the return on equity increased faster than the return on assets. Moreover, positive shocks of ICT patents diminish the cost/income ratio. That result corresponds with panel quantile regression results with tau 0.90 .

Unit root analyses were implemented for cost/income ratio and ICT patents. It was found that the cost/income ratio did not increase steadily, and ICT patent production did not increase steadily as well. Since there is no unit root problem, ICT patent production is mean-reverting. Therefore, OECD members, in general, shall regularly increase ICT patent production. If that increases can also be applied in banking sectors, more innovations such as robotic technologies and smart glasses can be applied to the banking sector.

In addition to econometric methods, robotic communication applications and smart glass applications were also discussed. In the future, it is highly probable that those applications will be used in the banking sector. Many employees worry about layoffs due to the emergence of robotic technologies. Nevertheless, with strict regulations, the adverse impact of robotic technologies can be prevented. On the other hand, when the pros are analyzed, many benefits can be thought for bank employees and bank customers. Robots can facilitate the burdensome works of bank employees. Robots can also protect banks from operational risks. With efficient applications of robotic technologies, banks can detect flaws, bottlenecks, and diminish costs.

Moreover, many customers in the world still can not use electronic banking properly. Many customers need a user-friendly interface, and many customers have concerns over security issues. With early warning systems, robotics applications can diminish security problems. With the usage of robotic technology with more user-friendly interfaces and robust security systems, electronic banking systems can become more widespread for the world banking system.

Besides, users also had to conduct a series of complex procedures with an AR machine in an experiment. Users were stated to have accomplished faster task using the AR app compared to LCD conditions (Henderson, Feiner, 2011). Although there is a lack of maturity in smart glass technology, Mühlematter and Donno (2016) mentioned that more than half of the 30 staff recommended smart glass technology to other staff in Credit Suisse. Moreover, The Vuzix M100 can reach the staff's surroundings without any extra effort. While this technology is being tested in industrial settings, a similar method can be used by a bank to recognize and identify objects in real-time automatically. It could have a considerable impact on a bank advisor or teller who needs to manually determine if a check is bogus (Deloitte, 2016). With the statements of Henderson and Feiner (2011), Mühlematter 
and Donno (2016), and Deloitte (2016), it can be indicated that it is probable that smart glasses can be used in banking operations.

After possessing a smart glasses prototype with no problems of battery and overheating and security and ergonomic problems, banks' research and development departments can do experiments with banks' staff for practical smart glass usage. During walking and sitting, the efficient utilization of smart glasses can change. Therefore, a comparative analysis of smart glass usage during walking and sitting can be measured by bank staff feedback.

OECD countries can increase ICT patents about robotic technologies and smart glasses. To make those technologies more applicable, banks can open new research and development laboratories and can have partnerships with universities, engineering firms, and business consulting firms. Before implementing these technologies, simulation analyses have to be done by banks. After the simulations, the pros and cons of robotic technologies and smart glass applications can be determined. After minimizing the errors, banks can update and release robotic and smart glass applications.

In addition to that, after robotic technologies and smart glass technology can be used inside the banks, bank headquarters can embark on new separate projects about the usage of robotic technology and smart glasses across the country. The duration of the projects can be one year. Before implementing those technologies, banks can distribute surveys to employees about their ideas of using smart glasses and robotic technologies. After implementing robotic and smart glass technologies, banks branch administration can distribute new surveys to banks employees about the benefits and drawbacks of smart glasses and robotic technologies. After conducting the comparative analysis between the two types of surveys, bank administration can have information about the pros and cons of robotic technology and smart glass usage in the bank branches. To have better scientific results, bank headquarters can apply those technologies to bank branches that locate across the country.

Due to security and privacy concerns, smart glass applications are still in the development phase. With user-friendly smart glasses and more secure applications, banks can implement smart glass technology. Moreover, not only smart glasses can be used for regular banking operations, but also smart glasses shall be developed for fraud detection such as overdraft cheques, fake money. Also, the interaction of robotic technologies and smart glass applications is necessary for the sustainability of the banking operations.

\section{References}

Abir, M., \& Chokri, M. (2010). Is financial innovation influenced by financial liberalization? Evidence from the Tunisian banking industry. Banks \& Bank Systems, 5(3), 97-111.

Agarwal, A., Arora, H., Dua, K. \& Cherian, M. (2017). Future of robotics in banking, International Journal of Informative \& Futuristic Research, 4(5), 6297-6320.

Akgul, S. (2019). Gözlüğünüz kalp atışınızı da takip edecek, Inovasyon Kültürü Dergisi, 44.

Albaraka Press Newsletter (2018), The first robot started working at Albaraka Turk, https://www.albaraka.com.tr/pdf/Albaraka-First-Robot-PR.pdf

Azuma, R. (1997). A survey of augmented reality. Presence Teleoperators Virtual Environments, 6(4) 355- 385 .

Baum, C.F. (2013). https://fmwww.bc.edu/EC-C/S2013/823/EC823.S2013.nn04.slides.pdf 
El Chaarani, H., \& El Abiad, Z. (2018). The impact of technological innovation on bank performance. Journal of Internet Banking and Commerce, 23(3), 1-33.

Chuong, V. L., Hung, P. D., \& Diep, V. T. (2019), Robotic process automation and opportunities for Vietnamese market. In Proceedings of the 2019 7th International Conference on Computer and Communications Management, 86-90.

Coras, E. L., \& Regneala, H. (2015). Reshaping innovation in the Romanian banking system, International Journal of Economic Practices and Theories, 5(3), 166-171.

Deloitte, (2016), https://www2.deloitte.com/content/dam/Deloitte/us/Documents/process-andoperations/us-cons-wearables-in-banking.pdf

Domeher, D., Frimpong, J. M., \& Appiah, T. (2014). Adoption of financial innovation in the Ghanaian banking industry. African Review of Economics and Finance, 6(2), 88-114.

Egeli, H.A., \& Egeli, P. (2007), İhracat-milli gelir ilişkisi: asya ülkeleri üzerine panel veri analizi. Uluslararası Asya ve Kuzey Afrika Çalışmaları Kongresi.

Gundogdu, A., \& Taskın, F. D. (2017). Analysis of the relationship between financial innovation and the performance of Turkish banking. International Review of Economics and Management, 5(3), 16-32.

Henderson, S.J., \& Feiner, S. (2011). Augmented reality in the psychomotor phase of a procedural task. 10th IEEE International Symposium on Mixed and Augmented Reality, 191-200.

Kołodziej, M. (2017). Virtual reality as the indicator of the modern banking. Nauki o Finansach, 2(31), 44-51.

Kumar, K. N., \& Balaramachandran, P. R. (2018). Robotic process automation-a study of the impact on customer experience in retail banking industry. Journal of Internet Banking and Commerce, 23(3), 1-27.

Mühlematter, T. \& Donno, F. (2016). Why smart bankers wear glasses: performance and user acceptance of smartglasses by bank employees. Proceedings of the 6th Mexican Conference on Human-Computer Interaction, pp.16-23.

Roberts, P. W., \& Amit, R. (2003). The dynamics of innovative activity and competitive advantage: The case of Australian retail banking, 1981 to 1995. Organization Science, 14(2), 107-122.

Saha, O., \& Dasgupta, P. (2018). A comprehensive survey of recent trends in cloud robotics architectures and applications. Robotics, 7(3), 47.

Schulz, M. (2005). Banking consolidation and financial innovation. Japanese Economy, 33(3), 2754.

Smart Glasses Hub, Smart Glasses- Everything you need to know, https://smartglasseshub.com/smart-glasses/

Qulix Systems (Jul 2016), How Smart Glasses Will Transform Banking, https://www.qulix.com/about/blog/smart-glasses-will-transform-banking/

Yavuz, A. A. \& Asık, E. G. (2017). Quantile Regression, Uluslararası Mühendislik Araştırma ve Geliştirme Dergisi, 9(2), 137-146. 